\title{
Synthesis of C-6 Methyl Substituted Benzothiazole Derivatives and Antifungal Activity against Aspergillus Niger
}

\author{
Akhilesh Gupta* \\ Department of Pharmaceutical Chemistry, Kunwar Haribansh Singh College of Pharmacy, India
}

Received: 眥 June 03, 2018; Published: 眥June 19, 2018

*Corresponding author: Akhilesh Gupta, Department of Science and Technology, Kunwar Haribansh Singh College of Pharmacy, Jaunpur (UP), India

\section{Abstract}

Life-threatening illness occurs due to Aspergillus species cause a spectrum of disease ranging from airway colonization. In case of respiratory tract, aspergilloma is the most common form of pulmonary involvement, which is usually accompanied by preexisting lung disease finally architectural abnormalities most commonly stem from tuberculosis, although other associated conditions, such as sarcoidosis, bronchiectasis, and neoplasm, have been documented.

Methodology: The present work comprised of synthesis and cyclization of substituted benzothiazole nucleus by reaction of substituted aniline with potassium thiocynate in presence of bromine in glacial acetic acid and ammonia under temperature control. Substituted benzothiazole then condensed with 2 (3 or 4)-nitrobenzoylchloride acid in presence of dry pyridine and acetone to get substituted nitrobenzamides. To the above product 2-nitroaniline, 3-nitroaniline, 4-nitroaniline in presence of DMF were treated to get newly synthesized derivatives (D-1 to D-09) through replacing at 7th position chlorine. Antifungal activity was performed against Aspergillus Niger by cup plate method (diffusion technique) using Griseoflavin as standard.

Result: Among, all newly synthesized derivatives compound D-5 showed potent antifungal activity against activity. Aspergillus Niger while compound D-6, D-8 and D-9 showed moderate inhibitory activity at both concentrations $50 \mu \mathrm{g} / \mathrm{ml}$ and $100 \mu \mathrm{g} / \mathrm{ml}$ as compared to standard.

Conclusion: In the present work efforts have been made to synthesized newer derivatives having methyl substitution at C- 6 position of benzothiazole while 2-(3 or 4)-aryl-NO2 considered as rotating substitution at C-2 and C-7 position of benzothiazole nucleus to find out influence of activity due to change in substitution position against Aspergillus Niger .

Keywords: Benzothiazole; Antifungal activity; 2-Substituted benzothiazole; 7-Substituted benzothiazole; Nitro benzothiazole; Cyclization of benzothiazole nucleus; Aspergillus Niger; Cup plate method (diffusion technique)

\section{Introduction}

Fungi of the genus Aspergillus are ubiquitous saprophytic and widespread presence in the environment; hundreds of Aspergillus spp. inhaled may by the average person per day [1]. Mucociliary clearance and phagocytosis by alveolar macrophages, basically involved to remove Aspergillus spp. from respiratory tract (RT), while polymorph nuclear neutrocytes cleared germinating spores and hyphae through degranulation and the release of oxidants [2]. Aspergillus spp. is capable to colonize in RT, even presence of these effective clearance mechanisms in the body for the elimination of inhaled fungi from the respiratory tracts of healthy individuals. The main target site of colonizing of Aspergillus spp. is injured lung tissue and epithelia. Although such colonization often has no clinical consequences, Aspergillus spp. can cause a variety of clinical manifestations depending on the immune status of the host $[3,4]$. Aryl nitro substitution at C-2 and C-7 position together with their parental nucleus benzothiazole constitute an important group of 
synthetic products that are of particular interest owing to their wide ranging biological activities [5-9]. Their principal medicinal role is reportedly in the field of medicinal chemistry. The biological activities of some of these compounds were previously evaluated for anti-tumor, anti-inflammatory, antibacterial and anti fungal activity [10-14]. In, the recent era development of resistance against existing antibacterial and anti-fungal agents, created demand of new research to combat the developed resistance with efficacy and safety. The synthesis of benzothiazole is an area of current interest because it belongs to an important class of heterocyclic compounds that found to be effective as antimicrobial and anti-inflammatory agents [15-18]. At present several methods for the synthesis and cyclization of benzothiazole have been reported. Since individual method has its own advantages and disadvantages, but the most common classical method for the synthesis of benzothiazole recently in use is based on cyclization of substituted aniline in the presence of potassium thiocyanate achieved through oxidation by bromine. Structure activity relationships of benzothiazoles have been of great interest because, change in $\mathrm{S}$ and $\mathrm{N}$, nucleophilicity with change of functional groups along with its biological activities [19]. Since it is well known that lead optimization is mainly based on the cyclization and structural elaboration by attachment of substituent groups either on the benzene or heterocyclic rings. Although, reported relationships between the structure of the heterocyclic scaffold and substituent groups reveal that the nature of the heterocyclic ring is the main base, associated with biological activity. It also reveals that change in biological activity with the presence of substituent in different positions of benzothiazole moiety [20-22]. The aim of this study was to synthesized and determines the antifungal activity of novel compounds against Aspergillus Niger to established further understanding of the biological and investigate structure-activity relationships among them.

\section{Materials and Methods}

\section{Synthesis of Substituted Benzothiazole (1-SB)}

Synthesis of substituted benzothiazole nucleus was achieved by adding $8 \mathrm{gm}(0.08 \mathrm{~mol})$ of potassium thiocyanate and $1.45 \mathrm{~g}$ $(0.01 \mathrm{~mol})$ of substituted aniline to $20 \mathrm{ml}$ cooled glacial acetic acid in such a way to temperature not exceeded above room temperature. Temperature of reaction was controlled by placing mixture in freezing mixture of ice and salt with mechanically stirring. Solution of $1.6 \mathrm{ml}$ of bromine in $6 \mathrm{ml}$ of glacial acetic acid was added using dropping funnel. Time taken for addition of bromine was around 105 minute with special precaution was taken that the temperature never rose beyond room temperature. When addition of bromine was completed the solution was stirred for 2 hours below room temperature and at room temperature for 10 hours. Then mixture allowed stand overnight to get an orange precipitate was settle at the bottom. $6 \mathrm{ml}$ water was added and heated at $850 \mathrm{C}$ on a steam bath and filtered hot (Filtrate-01). The residue was heated with $10 \mathrm{ml}$ of glacial acetic acid at $850 \mathrm{C}$ and filtered hot (Filtrate-02). The filtrate 01 and 02 were combined and cooled. Precipitate was collected when it neutralized with concentrated ammonia solution to $\mathrm{pH}$ 6. Finally treated with animal charcoal and recrystalised from benzene, ethanol of (1:1) to get substituted benzothiazole (1-SB, $66 \%$ yeild).

\section{Synthesis of Nitrobenzamide (2-SB, 3-SB, and 4-SB)}

Intermediate nitrobenzamide compound 2-SB, 3-SB and 4-SB were synthesized by dissolving $5.36 \mathrm{~g}(0.026 \mathrm{~mol})$ of substituted nitrobenzoylchloride in $50 \mathrm{ml}$ dry acetone. The solution was added drop wise with continuous stirring at room temperature into a solution of $5.22 \mathrm{~g}(0.026 \mathrm{~mol})$ of product of 1 -SB in dry pyridine $(50 \mathrm{ml})$. Stirring was continued for another 30 minutes after addition. Finally transferred into ice cold water $(200 \mathrm{ml})$ and recrystalized with ethanol.

\section{Synthesis of Compound D-1 to D-9}

The final novel compounds (D-1 to D-9) were synthesized by separate refluxing of $2.7 \mathrm{~g}(0.0075 \mathrm{~mol})$ of product $2-\mathrm{SB}, 3-\mathrm{SB}$ and 4-SB with $0.008 \mathrm{~mol}$ of 2 ( 3 or 4 ) nitro substituted aniline for 2 hrs in presence of DMF (dimethyl formamide). The mixture was cooled at room temperature and poured into crushed ice and solid separated after filtration. The separated solid was dried and recrystalized with super dry alcohol.

\section{Analytical Characterization}

During the synthesis the reaction progress was closely monitored by thin layer chromatography using solvent system butanol: ethyl acetate: benzene [1:2:1] and detection performed by exposing them to iodine vapors. Open capillaries method was used to determine melting points of the synthesized compounds. Structure elucidation of compounds were done by IR spectra ( $\mathrm{KBr}$ pellet technique) were recorded using a SHIMADZU (8400S), spectrophotometer. IR spectral study showed frequency range for $\mathrm{Ar}-\mathrm{C}=\mathrm{C}, \mathrm{C}=\mathrm{O}, \mathrm{C}-\mathrm{S}, \mathrm{C}-\mathrm{NO}$. $1 \mathrm{H}$ NMR spectra were recorded using CDCL3 as a solvent and tetramethylsilane (TMS) as an internal standard on Bruker AM 400 instrument (at $400 \mathrm{MHz}$ ).

\section{Antifungal activity against Aspergillus Niger}

The synthesized compounds are screened against selected fungal strains Aspergillus Niger by using diffusion method and griseoflavin used as a standard drug. The 48 hours old fungal culture inoculated into nutrient broth by following aseptic techniques and incubated for 48 hours at $37 \pm 20 \mathrm{C}$ in an incubator. This culture mixed with Potato-dextrose agar media $(20 \%)$ and poured into petriplates. After solidification five bores are made at equal distance by using sterile steel cork borer ( $8 \mathrm{~mm}$ in diameter). Into these cups different concentrations $(50 \mu \mathrm{g} / \mathrm{ml}$ and $100 \mu \mathrm{g} / \mathrm{ml})$ of standard drug and synthesized compounds along with control (Dimethyl formamide) introduced. After introduction of standard drug and compounds, these plates are placed in a refrigerator at 8-100C for two hours for proper diffusion of the drugs. After 2 hours of cold incubation, the petriplates are transferred to incubator and 
maintained at $37 \pm 20 \mathrm{C}$ for $24-36$ hours. After the incubation period, the plates were observed for zone of inhibition by using verniar scale. Results evaluated by comparing the zone of inhibition shown by the synthesized compounds with standard drug. The results are the mean value of zone of inhibition measured in millimeter of two preparation of sample (Synthesized compounds) and standard drug.

\section{Result and Discussion}

Benzothiazole contains Sulphar and nitrogen as heteroatom but impart biological activity while substitution at C-2, C-6 and C-7 position. Although, C-2 and C- 6 position in substituted aniline found to be the most positive center but $\mathrm{C}-2$ position behaves as a more electrophilic centre. However attack preferably at C-2 position, which was the electrophilic center and it is probable that bromine being as pseudo halogen, behaves as an electrophile by attacking this electrophilic center followed by replacement of hydrogen of $\mathrm{C}-2$ position as one hydrogen bromide while one bromine atom remain attached. Thiocyanogen replaced bromine and behaves as a pseudo halogen (electrophile) followed by elimination of potassium bromide. Rearrangement produces substituted benzothiazole through ring closure when $\mathrm{pH}$ adjusted at pH6 with ammonia.

In the present work efforts have been made to synthesized newer derivatives having methyl substitution at C- 6 position of benzothiazole while 2-(3 or 4)-aryl-NO2 considered as rotating substitution at C-2 and C-7 position of benzothiazole nucleus to find out influence of activity due to change in substitution position (Figure 1). The Basic fact behind frequent use of nitro group as substituent is that the bacteria only rarely acquire resistance; hence compound seems to be more effective against bacterial infection even it was revealed that inherent toxicity of nitro group is very low that allow compound to be safe also. Analytical characterization was performed using TLC, melting point, while structural elucidation was done by IR and NMR. Reaction progress was monitored by thin layer chromatography. It was found that the distance traveled by the sample was found to be different from that of the parent compound spotted along with it and confirmed that synthesized compounds were different from parent compound. Since all samples gave a single spot, the compounds were taken to be free from impurities. Analytical characterization data confirmed structure of newly synthesized compounds (D-1 to D-9). Structure of newly synthesized compounds confirmed by 1HNMR which clearly indicated a sharp characteristic signal at $7.14-7.60 \mathrm{ppm}$ is assigned to $\mathrm{NH}$ proton (benzothiazole) in all the synthesized compounds (Table 1). The synthesized compounds are screened against selected fungal strains Aspergillus Niger by using diffusion method at two concentration 50 and $10050 \mu \mathrm{g} / \mathrm{ml}$ using griseoflavin as a standard drug. In the screening, it was found that compound D-5 exhibited promising inhibitory activity while compound D-6, D-8, D-9 showed moderate activity and rest of compounds not compete for better activity or can be consider as mild active (Table 2).

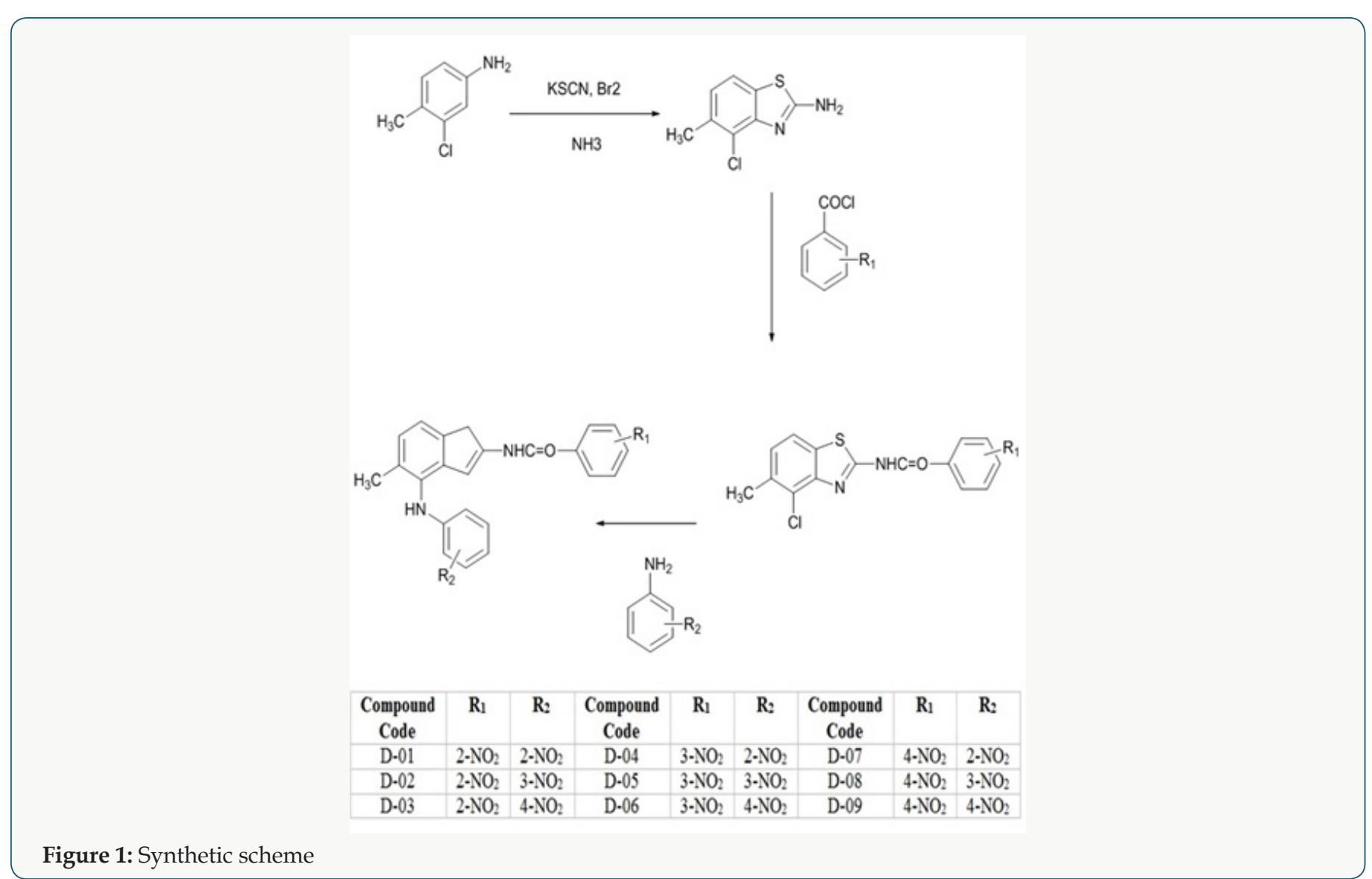


Table 1: Analytical characterization of newly synthesized compounds.

\begin{tabular}{|c|c|c|c|c|c|}
\hline Compound Code & \%Yield & Melting point (OC) & TLC (Rf value) & IR & 1HNMR (400Hz, DMSO-d6) \\
\hline D-1 & 74 & 265 & 0.48 & $\begin{array}{l}1469 \mathrm{~cm}^{-1} \mathrm{Ar} \mathrm{C}=\mathrm{C}, 1648 \mathrm{~cm}^{-1} \mathrm{C}=\mathrm{O} \\
1255 \mathrm{~cm}^{-1} \mathrm{C}-\mathrm{S}, 1540 \mathrm{~cm}^{-1} \mathrm{C}-\mathrm{NO}_{2} .\end{array}$ & $\begin{array}{c}\delta 7.61,7.64(\mathrm{~s}, 2 \mathrm{H}, \mathrm{NH}), \delta 3.37(\mathrm{~s}, \\
\left.3 \mathrm{H}, \mathrm{CH}_{3}\right), \delta 7.19-7.76(\mathrm{~m}, 10 \mathrm{H}, \\
\mathrm{Ar}-\mathrm{H})\end{array}$ \\
\hline D-2 & 71 & 259 & 0.52 & $\begin{array}{c}1424 \mathrm{~cm}^{-1} \mathrm{Ar} \mathrm{C}=\mathrm{C}, 1634 \mathrm{~cm}^{-1} \mathrm{C}=\mathrm{O} \\
1265 \mathrm{~cm}^{-1} \mathrm{C}-\mathrm{S}, 1547 \mathrm{~cm}^{-1} \mathrm{C}-\mathrm{NO}_{2} .\end{array}$ & $\begin{array}{c}\delta 7.58,7.62(\mathrm{~s}, 2 \mathrm{H}, \mathrm{NH}), \delta 3.35(\mathrm{~s}, \\
\left.3 \mathrm{H}, \mathrm{CH}_{3}\right), \delta 7.15-7.70(\mathrm{~m}, 10 \mathrm{H}, \\
\operatorname{Ar}-\mathrm{H})\end{array}$ \\
\hline D-3 & 65 & 268 & 0.51 & $\begin{array}{c}1423 \mathrm{~cm}^{-1} \mathrm{Ar} \mathrm{C}=\mathrm{C}, 1622 \mathrm{~cm}^{-1} \mathrm{C}=\mathrm{O} \\
1215 \mathrm{~cm}^{-1} \mathrm{C}-\mathrm{S}, 1534 \mathrm{~cm}^{-1} \mathrm{C}-\mathrm{NO}_{2} .\end{array}$ & $\begin{array}{c}\delta 7.63,7.75(\mathrm{~s}, 2 \mathrm{H}, \mathrm{NH}), \delta 3.33(\mathrm{~s}, \\
3 \mathrm{H}, \mathrm{CH} 3), \delta 7.17-7.72(\mathrm{~m}, 10 \mathrm{H}, \\
\text { Ar-H) }\end{array}$ \\
\hline D-4 & 68 & 270 & 0.55 & $\begin{array}{c}1421 \mathrm{~cm}^{-1} \mathrm{Ar} \mathrm{C}=\mathrm{C}, 1665 \mathrm{~cm}^{-1} \mathrm{C}=\mathrm{O} \\
1243 \mathrm{~cm}^{-1} \mathrm{C}-\mathrm{S}, 1537 \mathrm{~cm}^{-1} \mathrm{C}-\mathrm{NO}_{2} .\end{array}$ & $\begin{array}{c}\delta 7.65,7.79(\mathrm{~s}, 2 \mathrm{H}, \mathrm{NH}), \delta 3.39(\mathrm{~s}, \\
\left.3 \mathrm{H}, \mathrm{CH}_{3}\right), \delta 7.13-7.65(\mathrm{~m}, 10 \mathrm{H}, \\
\text { Ar-H) }\end{array}$ \\
\hline D-5 & 66 & 256 & 0.59 & $\begin{array}{c}1440 \mathrm{~cm}^{-1} \mathrm{Ar} \mathrm{C}=\mathrm{C}, 1629 \mathrm{~cm}^{-1} \mathrm{C}=\mathrm{O} \\
1217 \mathrm{~cm}^{-1} \mathrm{C}-\mathrm{S}, 1532 \mathrm{~cm}^{-1} \mathrm{C}-\mathrm{NO}_{2} .\end{array}$ & $\begin{array}{c}\delta 7.59,7.55(\mathrm{~s}, 2 \mathrm{H}, \mathrm{NH}), \delta 3.31(\mathrm{~s}, \\
\left.3 \mathrm{H}, \mathrm{CH}_{3}\right), \delta 7.23-7.71(\mathrm{~m}, 10 \mathrm{H} \\
\mathrm{Ar}-\mathrm{H})\end{array}$ \\
\hline D-6 & 70 & 269 & 0.48 & $\begin{array}{c}1421 \mathrm{~cm}^{-1} \mathrm{Ar} C=\mathrm{C}, 1615 \mathrm{~cm}^{-1} \mathrm{C}=\mathrm{C} \\
1212 \mathrm{~cm}^{-1} \mathrm{C}-\mathrm{S}, 1554 \mathrm{~cm}^{-1} \mathrm{C}-\mathrm{NO}_{2}\end{array}$ & $\begin{array}{c}\delta 7.65,7.81(\mathrm{~s}, 2 \mathrm{H}, \mathrm{NH}), \delta 3.34(\mathrm{~s}, \\
\left.3 \mathrm{H}, \mathrm{CH}_{3}\right), \delta 7.22-7.77(\mathrm{~m}, 10 \mathrm{H}, \\
\mathrm{Ar}-\mathrm{H})\end{array}$ \\
\hline D-7 & 55 & 264 & 0.65 & $\begin{array}{c}1443 \mathrm{~cm}^{-1} \mathrm{Ar} \mathrm{C}=\mathrm{C}, 1626 \mathrm{~cm}^{-1} \mathrm{C}=\mathrm{C} \\
1222 \mathrm{~cm}^{-1} \mathrm{C}-\mathrm{S}, 1543 \mathrm{~cm}^{-1} \mathrm{C}-\mathrm{NO}_{2}\end{array}$ & $\begin{array}{c}\delta 7.62,7.66(\mathrm{~s}, 2 \mathrm{H}, \mathrm{NH}), \delta 3.37(\mathrm{~s}, \\
\left.3 \mathrm{H}, \mathrm{CH}_{3}\right), \delta 7.17-7.70(\mathrm{~m}, 10 \mathrm{H}, \\
\mathrm{Ar}-\mathrm{H})\end{array}$ \\
\hline D-8 & 65 & 255 & 0.62 & $\begin{array}{c}1421 \mathrm{~cm}^{-1} \mathrm{Ar} \mathrm{C}=\mathrm{C}, 1621 \mathrm{~cm}^{-1} \mathrm{C}=\mathrm{O} \\
1258 \mathrm{~cm}^{-1} \mathrm{C}-\mathrm{S}, 1523 \mathrm{~cm}^{-1} \mathrm{C}-\mathrm{NO}_{2}\end{array}$ & $\begin{array}{c}\delta 7.62,7.81(\mathrm{~s}, 2 \mathrm{H}, \mathrm{NH}), \delta 3.41(\mathrm{~s}, \\
\left.3 \mathrm{H}, \mathrm{CH}_{3}\right), \delta 7.21-7.70(\mathrm{~m}, 10 \mathrm{H}, \\
\operatorname{Ar}-\mathrm{H})\end{array}$ \\
\hline D-9 & 58 & 267 & 0.54 & $\begin{array}{c}1467 \mathrm{~cm}^{-1} \mathrm{Ar} \mathrm{C}=\mathrm{C}, 1660 \mathrm{~cm}^{-1} \mathrm{C}=\mathrm{C} \\
1244 \mathrm{~cm}^{-1} \mathrm{C}-\mathrm{S}, 1521 \mathrm{~cm}^{-1} \mathrm{C}-\mathrm{NO}_{2}\end{array}$ & $\begin{array}{c}\delta 7.61,7.74(\mathrm{~s}, 2 \mathrm{H}, \mathrm{NH}), \delta 3.32(\mathrm{~s}, \\
\left.3 \mathrm{H}, \mathrm{CH}_{3}\right), \delta 7.13-7.79(\mathrm{~m}, 10 \mathrm{H}, \\
\text { Ar-H) }\end{array}$ \\
\hline
\end{tabular}

Table 2: Result of antifungal activity.

\begin{tabular}{|c|c|c|}
\hline \multirow{2}{*}{ Compound Code } & \multicolumn{2}{|c|}{ Aspergillus niger } \\
\cline { 2 - 3 } & $\mathbf{5 0} \mathbf{\mu g} / \mathbf{m l}$ & $\mathbf{1 0 0} \boldsymbol{\mu g} / \mathbf{m l}$ \\
\hline Griseoflavin & 19 & 26 \\
\hline D-1 & 09 & 18 \\
\hline D-2 & 10 & 16 \\
\hline D-3 & 10 & 15 \\
\hline D-4 & 07 & 10 \\
\hline D-5 & 17 & 24 \\
\hline D-6 & 13 & 19 \\
\hline D-7 & 08 & 18 \\
\hline D-8 & 12 & 18 \\
\hline D-9 & 11 & 17 \\
\hline
\end{tabular}

\section{Conclusion}

In the present work substituted benzothiazole nucleus synthesized from substituted aniline followed by condensation with nitrobenzoylchloride. To the above product 2-nitroaniline, 3-nitroaniline, 4-nitroaniline in presence of DMF were treated to get newly synthesized derivatives (D-1 to D-09) through replacing at 7 th position chlorine. Analytical characterization data confirmed structure of newly synthesized compounds (D-1 to D-9). Synthesized compounds were evaluated for antifungal activity using fungal strain of Aspergillus niger by cup plate method (diffusion technique) at two different concentration $50 \mu \mathrm{g} / \mathrm{ml}$ and $100 \mu \mathrm{g} / \mathrm{ml}$. Among, all newly synthesized derivatives compound D-5 showed potent.

\section{References}

1. Hospenthal DR, Kwon-Chung KJ, Bennett JE (1998) Concentrations of airborne Aspergillus compared to the incidence of invasive aspergillosis: lack of correlation. Med Mycol 36 (3): 165-168.

2. Dagenais TR, Keller NP (2009) Pathogenesis of Aspergillus fumigatus in invasive aspergillosis. Clin Microbiol Rev 22(3): 447-465.

3. Walsh TJ, Anaissie EJ, Denning DW, Herbrecht R, Kontoyiannis DP, et al. (2008) Treatment of aspergillosis: clinical practice guidelines of the Infectious Diseases Society of America. Clin Infect Dis 46(3): 327-360.

4. Hope WW, Walsh TJ, Denning DW (2005) The invasive and saprophytic syndromes due to Aspergillus spp. Med Mycol 43(Suppl 1): S207-S238.

5. Bradshaw TD, Wrigley S, Shi DF, Schultz RJ, Stevens MFG, et al. (1998) 2-(4-aminophenyl) benzothiaozles: novel agents with selective profiles of in vitro antitumor activity. Br J Cancer 77(5): 745-752.

6. Alang G, Kaur R, Singh A, Budhlakoti P, Singh A, et al. (2010) Synthesis, Characterization and antifungal activity of certain (E)-1(1-(substitutedphenyl) ethylidene)-2-(6-methylbenzo[d]thiazol-2yl) hydrazine analogues. International Journal of Pharmaceutical \& Biological Archives 1(1): 56-61.

7. Suresh SH, Venkateshwara RJ, Jayaveera KN (2010) Synthesis of 4-(2'-substituted benzothiaozles)-5-mercapto-3-(substituted)-1,2,4triazole derivatives for possible ant microbiological activities. Research Journal of Pharmaceutical, Biological and Chemical Sciences 1(4): 635640. 
8. Basavaraja KM, Somashekhar B, Shivakumar B (2010) Synthesis of 2-[(1-phenyl) (aryl) azo] methyleneimino-6-chloro/ fluoro benzothiazoles and their antibacterial activity. International Journal of PharmTech Research 2(2): 1139-1143.

9. Vedavathi M, Somashekar, Sreenivasa GM, Jayachandran E (2010) Synthesis, characterization and antimicrobial activity of fluoro benzothiaozle incorporated with 1,3,4-thiadiazole. Journal of Pharmaceutical sciences and research 2(1): 53-63.

10. Pandurangan A, Sharma A, Sharma N, Sharma PK, Visht S (2010) Synthesis and structural studies of novel benzothiazole derivative and evaluation of their antimicrobial activity. Der pharma Chemica 2(3): 316-324.

11. Rajeeva B, Srinivasulu N, Shatakumar SM (2009) Synthesis and antimicrobial activity of some new 2-substituted benzothiazole derivatives. E-Journal of Chemistry 6(3): 775-779.

12. Malik J, Manvi FV, Nanjwade BK, Singh S (2009) Synthesis and screening of some new 2-amino substituted benzothiazole derivatives for antifungal activity. Drug Invention Today 1(1): 32-34.

13. Patel NB, Shaikh FM (2010) Synthesis of new pyridine based 4-thiazolidinones incorporated benzothiazoles and evaluation of their antimicrobial activity. Journal of Sciences 21(2): 121-129.

14. Barot HK, Mallika G, Sutariya BB, Shukla J, Nargund LVG (2010) Synthesis of nitrogen mustards of flouro-benzothiazoles of pharmacological interest. Research Journal of Pharmaceutical, Biological and Chemical Sciences 1(1): 124-129.

15. Dua R, Sonwane SK, Srivastava SK, Srivastava SD (2010) Greener and expeditious synthesis of 2-azetidinone derivative from 2-mercaptobenzothiazole and their pharmacological screening of the compounds using microwave irradiation. World Journal of Chemistry 5(1): 52-56.
16. Bhusari KP, Amnerkar Nd, Khedekar PB, Kale MK, Bhole RP (2008) Synthesis and in vitro antimicrobial activity of some new 4-amino- $N$ (1,3-Benzothiazol-2-yl) benzenesulphonamide derivatives. Asian J. Research Chem. 1(2): 53-58.

17. Sathe BS, Jayachandran E, Jagtap VA, Sreenivasa GM (2011) Anthelmintic activity of newly synthesized moieties of fluoro benzothiazole Schiff's bases. Research Journal of Pharmaceutical, Biological and Chemical Sciences 2(1): 510-515.

18. Sreenivasa GM, Jyachandran E, Shivakumar B, Jayaraj KK, Kumar V (2009) Synthesis of bioactive molecule fluoro benzothiazole comprising potent heterocyclic moieties for anthelmintic activity. Arch. Pharm. Sci. \& Res. 1(2): 150-157.

19. Venkatesh P, Pandeya SN (2009) Synthesis, characterization and antiinflammatory activity of some 2-amino benzothiazole derivatives. International Journal of ChemTech research 1(4): 1354-1358.

20. Shashank D, Vishawanth T, Prasha Md A, Balasubramaniam V, Nagendra A, et al. (2009) Synthesis of some substituted benzothiazole derivatives and its biological activities. International Journal of ChemTech Research 1(4): 1224-1231.

21. Kaur H, Kumar S, Singh I, Saxena K, Kumar A (2010) Synthesis, characterization and biological activity of various substituted benzothiazole derivatives. Digest Journal of Nanomaterials and Biostructures 5(1): 67-76.

22. Muttu CT, Bhanushali MD, Hipparagi SM, Tikare VP, Karigar A (2010) Microwave assisted synthesis and evaluation of some fluoro, chloro 2-N(substituted schiff's bases) aminobenzothiazoles derivatives for their anti-inflammatory activity. International Journal of Research in Ayurveda \& Pharmacy 1(2): 522-528.

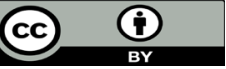

This work is licensed under Creative Commons Attribution 4.0 License

To Submit Your Article Click Here:

Submit Article
Theranostics of Respiratory \& Skin Diseases

DOI: $10.32474 /$ TRSD.2018.01.000106

\section{TRSD}

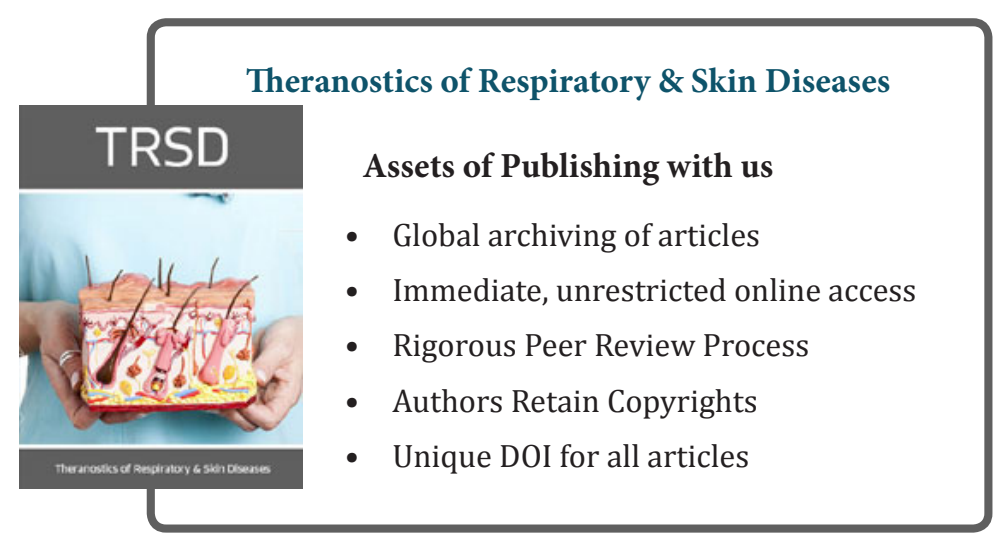

